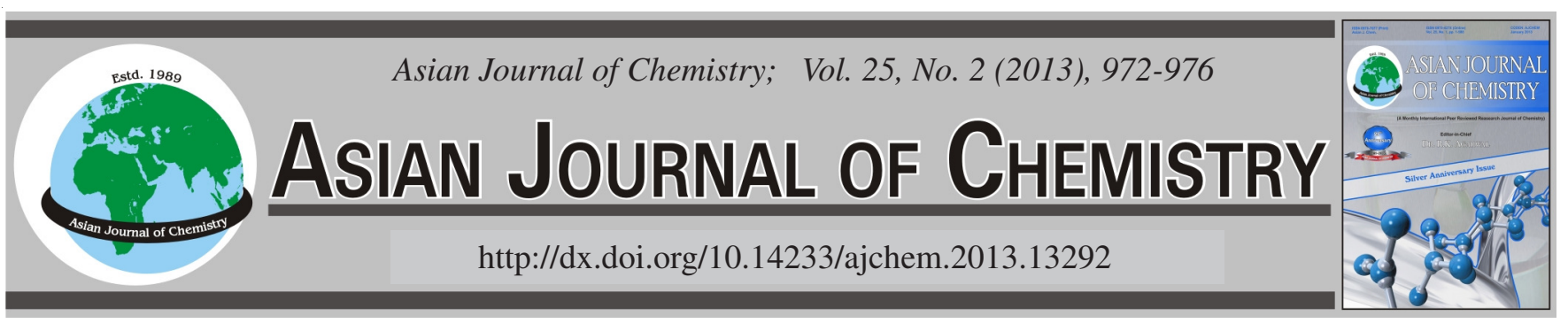

\title{
Synthesis and Characterization of Organotin(IV) Complexes Derivatives of Methyl- and Nitro- Substituted Monocarboxylic Acid: Preliminary in vitro Antibacterial Screening Activity
}

\footnotetext{
Yip-Foo Win ${ }^{1,2, *}$, Chen-Shang Choong ${ }^{1}$, Sie-Tiong HA $^{1}$, Siang-Guan TeOH ${ }^{2, *}$ and Naser Eltaher Eltayeb ${ }^{2,3}$

${ }^{1}$ Department of Chemical Science, Faculty of Science, Universiti Tunku Abdul Rahman, Perak Campus, Jalan Universiti, Bandar Barat, 31900 Kampar, Perak, Malaysia

${ }^{2}$ School of Chemical Sciences, Universiti Sains Malaysia, 11800 Minden Penang, Pulau Pinang, Malaysia

${ }^{3}$ Department of Chemistry, Faculty of Pure and Applied Sciences, International University of Africa, Khartoum, Sudan

*Corresponding author: Fax: +60 5 4661676; Tel: +60 5 4688888; E-mail: williamyfw@yahoo.com

\begin{abstract}
Organotin(IV) carboxylate complexes derivatives of 3-methyl-4-nitrobenzoic acid (3- $\left.\mathrm{CH}_{3}-4-\mathrm{NO}_{2}-\mathrm{C}_{6} \mathrm{H}_{3} \mathrm{COOH}\right)$ and 4-methyl-3-nitrobenzoic acid (4- $\left.\mathrm{CH}_{3}-3-\mathrm{NO}_{2}-\mathrm{C}_{6} \mathrm{H}_{3} \mathrm{COOH}\right)$ have been successfully synthesized. Two dibutyltin(IV) complexes with the general formulae $\left\{\left[\mathrm{X}-\mathrm{CH}_{3}-\right.\right.$ $\left.\left.\mathrm{Y}-\mathrm{NO}_{2}-\mathrm{C}_{6} \mathrm{H}_{3} \mathrm{COO}\left(\mathrm{C}_{4} \mathrm{H}_{9}\right)_{2} \mathrm{Sn}\right]_{2} \mathrm{O}\right\}_{2}(\mathrm{X}=$ meta, $\mathrm{Y}=$ para $1 ; \mathrm{X}=$ para, $\mathrm{Y}=$ meta 3$)$ and another two triphenyltin(IV) complexes with the general formulae $\mathrm{X}-\mathrm{CH}_{3}-\mathrm{Y}-\mathrm{NO}_{2}-\mathrm{C}_{6} \mathrm{H}_{3} \mathrm{COO}\left(\mathrm{C}_{6} \mathrm{H}_{5}\right)_{3} \mathrm{Sn} \cdot \mathrm{CH}_{3} \mathrm{OH}(\mathrm{X}=$ meta, $\mathrm{Y}=$ para $2 ; \mathrm{X}=$ para, $\mathrm{Y}=$ meta 4 ) were successfully synthesized. The acids and complexes 1-4 obtained were characterized quantitatively and qualitatively. Results of the infrared and NMR spectroscopy on the acids and complexes showed that the coordination took place via oxygen atoms from the carboxylate anions. Based on the spectroscopy studies indicated that one methanol molecule also take part in the coordination to tin(IV) atoms moiety in complexes 2 and 4 resulting the tin(IV) atoms exhibited five coordination. From the preliminary in vitro antibacterial screening activity, triphenyltin(IV) complexes ( $\mathbf{2}$ and $\mathbf{4}$ ) showed better activity compared to diorganotin(IV) complexes (1 and $\mathbf{3}$ ).
\end{abstract}

Key Words: Organotin(IV) complexes, Synthesis, Characterization, In vitro antibacterial activity.
}

\section{INTRODUCTION}

Numerous studies on organotin(IV) complexes have been carried out in order to study its biological properties against bacterial, fungal and cancer cells line ${ }^{1-8}$. In fact, organotin(IV) complexes are extensively studied due to its coordination geometries as well as structural diversity (monomer, dimeric, hexameric and oligomeric) $)^{9-13}$.

In this paper, we report on the synthesis and structural characterization of new organotin(IV) carboxylate complexes derived from 3-methyl-4-nitrobenzoic acid and 4-methyl-3nitrobenzoic acid. Moreover, the preliminary in vitro antibacterial screening activity of the complexes obtained are carried out and the results are reported herein.

\section{EXPERIMENTAL}

All the reagents, starting materials as well as the solvents were purchased commercially and used without any further purification. The melting points were determined in an open capillary and were uncorrected. Elemental C, H and $\mathrm{N}$ analyses were carried out on a Perkin-Elmer 2400 CHN Elemental Analyzer. Tin was determined gravimetrically by igniting a known quantity of each complex to $\mathrm{SnO}_{2}$. Infrared spectra were recorded using a Perkin-Elmer System 2000 FTIR spectrophotometer as a $\mathrm{KBr}$ disc in the frequency range of 4000-400 $\mathrm{cm}^{-1}$. The spectra for ${ }^{1} \mathrm{H},{ }^{1} \mathrm{H}-{ }^{13} \mathrm{C}$ HMQC and ${ }^{119} \mathrm{Sn}$ NMR were recorded on a Bruker AC-P 400 MHz FTNMR spectrometer and ${ }^{13} \mathrm{C}$ NMR was recorded on a Bruker AC-P 300MHz FTNMR spectrometer using deuterated $\mathrm{CDCl}_{3}$ and DMSO- $d_{6}$ as the solvent and tetramethylsilane, TMS as the internal standard.

Preliminary in vitro antibacterial screening activity: The synthesized complexes and parent acids were screened for their in vitro antibacterial activity against three Gramnegative (Escherichia coli, Pseudomonas aeruginosa and Klebsiella pneumoniae) and two Gram-positive (Bacillus subtilis and Staphylococcus aureus) bacterial strains, by inhibition zone method using agar well diffusion method. The seeded agar (nutrient agar medium) was prepared by cooling the molten agar to $40{ }^{\circ} \mathrm{C}$ and then adding bacterial inoculums containing approximately $10^{4}-10^{6}$ colony forming units (CFU)/ $\mathrm{mL}$. The bacterial inoculums were spread on the plate containing agar medium and even coverage was ensured before the agar solidified. The complexes were dissolved in DMSO to 
prepare $1 \mathrm{mg} / \mathrm{mL}$ concentration. By using a sterile metallic borer, the wells ( $6 \mathrm{~mm}$ in diameter) were dug and the standard drugs and complexes were introduced into the respective wells. The plates were incubated immediately at $37^{\circ} \mathrm{C}$ for $20-24 \mathrm{~h}$. The activity was determined by measuring the diameter of the inhibition zone (in $\mathrm{mm}$ ).

Preparation of sodium salts: The sodium salts of the acids were obtained by heating under reflux a 1:1 molar mixture of sodium hydroxide, $\mathrm{NaOH}$ and respective acid in ethanol $(50 \mathrm{~mL})$ for $2 \mathrm{~h}$. After a few days, white precipitates were obtained. Sodium salt of 3-methyl-4-nitrobenzoic acid: FTIR as $\mathrm{KBr}$ disc $\left(\mathrm{cm}^{-1}\right)$ selected data: $v(\mathrm{COO})_{\text {as }} 1635$, $v(\mathrm{COO})_{\mathrm{s}}$ 1356. Sodium salt of 4-methyl-3-nitrobenzoic acid: FTIR as $\mathrm{KBr}$ disc $\left(\mathrm{cm}^{-1}\right)$ selected data: $v(\mathrm{COO})_{\text {as }} 1650$, $v(\mathrm{COO})_{\mathrm{s}} 1354$.

\section{Synthesis of complexes}

Preparation of $\left\{\left[3-\mathrm{CH}_{3}-4-\mathrm{NO}_{2}-\mathrm{C}_{6} \mathrm{H}_{3} \mathrm{COO}\left(\mathrm{C}_{4} \mathrm{H}_{9}\right)_{2}\right.\right.$ $\mathbf{S n}]_{2} \mathrm{O}_{2}$ (1): Complex 1 was prepared by heating under reflux a 1:1 molar mixture of dibutyltin(IV) oxide $(0.49 \mathrm{~g}, 2 \mathrm{mmol})$ and 3-methyl-4-nitrobenzoic acid ( $0.36 \mathrm{~g}, 2 \mathrm{mmol})$ in acetone $(50 \mathrm{~mL})$ as solvent and the mixture was heated under reflux for $2 \mathrm{~h}$. After few days, yellow crystals $(0.77 \mathrm{~g}, 61.0 \%$ yield $)$ were collected. m.p. 216.7-217.1 ${ }^{\circ} \mathrm{C}$. Analysis for $\mathrm{C}_{64} \mathrm{H}_{96} \mathrm{~N}_{4} \mathrm{O}_{18} \mathrm{Sn}_{4}: \mathrm{C}, 45.55 ; \mathrm{H}, 5.93 ; \mathrm{N}, 3.20 ; \mathrm{Sn}, 16.95 \%$. Calculated for $\mathrm{C}_{64} \mathrm{H}_{96} \mathrm{~N}_{4} \mathrm{O}_{18} \mathrm{Sn}_{4}: \mathrm{C}, 45.64 ; \mathrm{H}, 5.75 ; \mathrm{N}, 3.33$; Sn, $17.09 \%$. FTIR as $\mathrm{KBr}$ disc $\left(\mathrm{cm}^{-1}\right): \mathrm{v}(\mathrm{C}-\mathrm{H})$ aromatic 3069 , $v(\mathrm{C}-\mathrm{H})$ saturated 2958, 2927, 2861; v(COO) as 1635, 1523; $v(\mathrm{COO})_{\mathrm{s}} 1306,1339 ; \mathrm{v}\left(\mathrm{NO}_{2}\right)$ 1523, v(Sn-O-Sn) 635, v(SnC) $535, \mathrm{v}(\mathrm{Sn}-\mathrm{O}) 469 .{ }^{1} \mathrm{H} \mathrm{NMR}(\mathrm{ppm})\left(\mathrm{CDCl}_{3}\right)$ : $\delta$ : benzene protons $7.99(\mathrm{~s}, 12 \mathrm{H})$; methyl, $\mathrm{CH}_{3} 2.70(\mathrm{~s}, 12 \mathrm{H})$; butyl, $\mathrm{CH}_{3}$ $0.81(\mathrm{t}, 6.7 \mathrm{~Hz}, 12 \mathrm{H}), 0.89$ (t, $7.1 \mathrm{~Hz}, 12 \mathrm{H}) ; \mathrm{CH}_{2} 1.31-1.45$ (m, 16H); $\mathrm{CH}_{2} 1.65-1.75$ (m, 32H). ${ }^{13} \mathrm{C} \mathrm{NMR}(\mathrm{ppm})\left(\mathrm{CDCl}_{3}\right)$ : $\delta$ : benzene carbons $124.87,128.57,133.61,134.49,137.36$, 151.94; $\mathrm{CH}_{3}$ 20.47; butyl 13.87, 13.96, 27.08, 27.13, 27.88, 28.12, 29.09, 30.70; COO 171.38. ${ }^{119} \mathrm{Sn} \mathrm{NMR}(\mathrm{ppm})\left(\mathrm{CDCl}_{3}\right)$ : $\delta:-206.97,-208.09$.

Preparation of 3- $\mathrm{CH}_{3}-4-\mathrm{NO}_{2}-\mathrm{C}_{6} \mathrm{H}_{3} \mathrm{COO}\left(\mathrm{C}_{6} \mathrm{H}_{5}\right)_{3} \mathrm{Sn}$ $\mathrm{CH}_{3} \mathrm{OH}$ (2): Complex 2 was obtained by heating under reflux a 1:1 molar mixture of triphenyltin(IV) hydroxide $(0.73 \mathrm{~g}$, $2 \mathrm{mmol})$ and 3-methyl-4-nitrobenzoic acid (0.36 g, $2 \mathrm{mmol})$ in a mixture of methanol/ethanol $(1: 1,60 \mathrm{~mL})$ for $2 \mathrm{~h}$. After few days, yellow solids $(0.77 \mathrm{~g}, 68.8 \%$ yield $)$ were collected. m.p. 95.3-96.1 ${ }^{\circ} \mathrm{C}$. Analysis for $\mathrm{C}_{27} \mathrm{H}_{25} \mathrm{~N}_{1} \mathrm{O}_{5} \mathrm{Sn}$ : C, 57.42; $\mathrm{H}$, 3.92; N, 2.45; Sn, $20.33 \%$. Calculated for $\mathrm{C}_{27} \mathrm{H}_{25} \mathrm{~N}_{1} \mathrm{O}_{5} \mathrm{Sn}: \mathrm{C}$, 57.68; H, 4.48; N, 2.49; Sn, $21.11 \%$. FTIR as $\mathrm{KBr} \operatorname{disc}\left(\mathrm{cm}^{-1}\right)$ : $v(\mathrm{C}-\mathrm{H})$ aromatic 3068, 3050; $v(\mathrm{C}-\mathrm{H})$ saturated 2991, 2933; $v(\mathrm{COO})_{\text {as }} 1619, v(\mathrm{COO})_{\mathrm{s}} 1371, v\left(\mathrm{NO}_{2}\right) 1510, v(\mathrm{Sn}-\mathrm{O}) 449$. ${ }^{1} \mathrm{H}$ NMR (ppm) $\left(\mathrm{CDCl}_{3}\right)$ : $\delta$ : phenyl protons 7.54-7.58 (m, 9H); 7.86-7.91 (m, 6H); benzene $7.99(\mathrm{~d}, 8.4 \mathrm{~Hz}, 1 \mathrm{H}) ; 8.12(\mathrm{~d}, 7.9$ $\mathrm{Hz}, 1 \mathrm{H}) ; 8.16$ (s, 1H); methyl, $\mathrm{CH}_{3} 2.65$ (s, 3H); $\mathrm{CH}_{3} \mathrm{OH} 3.49$ $(\mathrm{s}, 3 \mathrm{H}) .{ }^{13} \mathrm{C} \mathrm{NMR}(\mathrm{ppm})\left(\mathrm{CDCl}_{3}\right)$ : $\delta$ : phenyl carbons $\mathrm{C}_{\text {ipso }}$ $138.31(633.6 \mathrm{~Hz}), \mathrm{C}_{\text {ortho }} 137.31(48.2 \mathrm{~Hz}), \mathrm{C}_{\text {meta }} 129.09$ (63.7 $\mathrm{Hz}), \mathrm{C}_{\text {para }} 130.84(12.3 \mathrm{~Hz})$; benzene $124.75,129.39,133.56$, 135.28, 138.05, 152.12; $\mathrm{CH}_{3} 20.31 ; \mathrm{CH}_{3} \mathrm{OH} 51.06 ; \mathrm{COO}$ 170.98. ${ }^{119} \mathrm{Sn}$ NMR (ppm) $\left(\mathrm{CDCl}_{3}\right): \delta:-103.30$.

Preparation of $\left\{\left[4-\mathrm{CH}_{3}-3-\mathrm{NO}_{2}-\mathrm{C}_{6} \mathrm{H}_{3} \mathrm{COO}\left(\mathrm{C}_{4} \mathrm{H}_{9}\right)_{2}\right.\right.$ $\left.\mathbf{S n}]_{2} \mathbf{O}\right\}_{2}(3)$ : This complex was prepared by a similar method to those described for complex 1, except substituting 3-methyl4-nitrobenzoic acid with 4-methyl-3-nitrobenzoic acid. Acetone $(50 \mathrm{~mL})$ was used as solvent and the mixture was heated under reflux for $3 \mathrm{~h}$. A clear yellow transparent solution was isolated by filtration and kept in a bottle. After few days, yellow crystals (0.90 g, 71.3\% yield) were collected. m.p. 209.3-209.9 ${ }^{\circ} \mathrm{C}$. Analysis for $\mathrm{C}_{64} \mathrm{H}_{96} \mathrm{~N}_{4} \mathrm{O}_{18} \mathrm{Sn}_{4}$ : C, 45.46; H, 5.52; N, 3.25; $\mathrm{Sn}$, $16.99 \%$. Calculated for $\mathrm{C}_{64} \mathrm{H}_{96} \mathrm{~N}_{4} \mathrm{O}_{18} \mathrm{Sn}_{4}$ : C, 45.64; H, 5.75; $\mathrm{N}, 3.33$; Sn, $17.69 \%$. FTIR as $\mathrm{KBr} \operatorname{disc}\left(\mathrm{cm}^{-1}\right): \mathrm{v}(\mathrm{C}-\mathrm{H})$ aromatic 3095, v(C-H) saturated 2957, 2927, 2870; v(COO) as 1620, 1530; $v(\mathrm{COO})_{\mathrm{s}} 1341,1407 ; \mathrm{v}\left(\mathrm{NO}_{2}\right)$ 1530, v(Sn-O-Sn) 636, $v(\mathrm{Sn}-\mathrm{O}) 480 .{ }^{1} \mathrm{H} \mathrm{NMR}(\mathrm{ppm})\left(\mathrm{CDCl}_{3}\right)$ : $\delta$ : benzene protons $7.52(\mathrm{~d}, 6.9 \mathrm{~Hz}, 4 \mathrm{H}) ; 8.21$ (d, $7.6 \mathrm{~Hz}, 4 \mathrm{H}) ; 8.61$ (s, 4H); methyl, $\mathrm{CH}_{3} 2.72(\mathrm{~s}, 12 \mathrm{H})$; butyl, $\mathrm{CH}_{3} 0.77$ (t, $\left.6.9 \mathrm{~Hz}, 12 \mathrm{H}\right), 0.89$ (t, $7.2 \mathrm{~Hz}, 12 \mathrm{H}) ; \mathrm{CH}_{2} 1.28-1.45(\mathrm{~m}, 16 \mathrm{H}) ; \mathrm{CH}_{2}$ 1.63-1.78 (m, $32 \mathrm{H}) .{ }^{13} \mathrm{C}$ NMR $(\mathrm{ppm})\left(\mathrm{CDCl}_{3}\right)$ : $\delta$ : benzene carbons 126.37, 132.99, 133.37, 134.38, 138.03, 149.54; $\mathrm{CH}_{3}$ 20.95; butyl 13.87, 14.01, 26.34, 27.14, 28.18, 28.43, 29.18, 30.56; COO 170.97. ${ }^{119} \mathrm{Sn} \mathrm{NMR}(\mathrm{ppm})\left(\mathrm{CDCl}_{3}\right): \delta:-207.39,-211.19$.

Preparation of 4- $\mathrm{CH}_{3}-3-\mathrm{NO}_{2}-\mathrm{C}_{6} \mathrm{H}_{3} \mathrm{COO}\left(\mathrm{C}_{6} \mathrm{H}_{5}\right)_{3} \mathrm{Sn} \cdot$ $\mathrm{CH}_{3} \mathrm{OH}$ (4): Complex 4 was prepared by a similar method to those described for complex 2, except replacing 3-methyl-4nitrobenzoic acid with 4-methyl-3-nitrobenzoic acid and methanol $(50 \mathrm{~mL})$ was utilized in the synthesis. After few days, yellow solids ( $0.68 \mathrm{~g}, 60.7 \%$ yield) were collected. m.p. 133.7$134.3{ }^{\circ} \mathrm{C}$. Analysis for $\mathrm{C}_{27} \mathrm{H}_{25} \mathrm{~N}_{1} \mathrm{O}_{5} \mathrm{Sn}$ : C, 57.80; H, 4.01; N, 2.43; Sn, $20.82 \%$. Calculated for $\mathrm{C}_{27} \mathrm{H}_{25} \mathrm{~N}_{1} \mathrm{O}_{5} \mathrm{Sn}: \mathrm{C}, 57.68 ; \mathrm{H}$, 4.48; N, 2.49; Sn, $21.11 \%$. FTIR as KBr disc $\left(\mathrm{cm}^{-1}\right): \mathrm{v}(\mathrm{C}-\mathrm{H})$ aromatic 3065, v(C-H) saturated 2981, 2932, 2864; $\mathrm{v}(\mathrm{COO})_{\text {as }}$ $1641, v(\mathrm{COO})_{\mathrm{s}} 1336, v\left(\mathrm{NO}_{2}\right) 1529, \mathrm{v}(\mathrm{Sn}-\mathrm{O}) 448 .{ }^{1} \mathrm{H}$ NMR (ppm) $\left(\mathrm{CDCl}_{3}\right)$ : $\delta$ : phenyl protons 7.48-7.51 (m, 9H); 7.71$7.88(\mathrm{~m}, 6 \mathrm{H})$; benzene $7.38(\mathrm{~d}, 7.9 \mathrm{~Hz}, 1 \mathrm{H}) ; 8.20(\mathrm{~d}, 7.9 \mathrm{~Hz}$, $1 \mathrm{H}) ; 8.68$ (s, 1H); methyl $\mathrm{CH}_{3} 2.62$ (s, 3H); $\mathrm{CH}_{3} \mathrm{OH} 3.47$ (s, $3 \mathrm{H}) .{ }^{13} \mathrm{C} \mathrm{NMR}(\mathrm{ppm})\left(\mathrm{CDCl}_{3}\right)$ : $\delta$ : phenyl carbons $\mathrm{C}_{\text {ipso }} 138.22$, $\mathrm{C}_{\text {ortho }} 137.32(49.1 \mathrm{~Hz}), \mathrm{C}_{\text {meta }} 129.48(65.1 \mathrm{~Hz}), \mathrm{C}_{\text {para }} 130.82$ (13.3 Hz); benzene 127.12, 130.53, 133.13, 134.80, 137.97, 149.58; $\mathrm{CH}_{3}$ 20.91; COO 170.98. ${ }^{119} \mathrm{Sn} \mathrm{NMR} \mathrm{(ppm)}\left(\mathrm{CDCl}_{3}\right)$ :

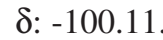

3-Methyl-4-nitrobenzoic acid, 3- $\mathrm{CH}_{3}-4-\mathrm{NO}_{2}-\mathrm{C}_{6} \mathrm{H}_{3} \mathrm{COOH}$ : The parent acid, 3-methyl-4-nitrobenzoic acid, 3- $\mathrm{CH}_{3}-4-\mathrm{NO}_{2}-$ $\mathrm{C}_{6} \mathrm{H}_{3} \mathrm{COOH}$ was purchased from Acros Organics and used without any further purification. FTIR as $\mathrm{KBr} \operatorname{disc}\left(\mathrm{cm}^{-1}\right)$ : selected data: $\mathrm{v}(\mathrm{OH}) 2827-2552, \mathrm{v}(\mathrm{COO})_{\text {as }} 1682, \mathrm{v}(\mathrm{COO})_{\mathrm{s}}$ 1311. ${ }^{1} \mathrm{H}$ NMR (ppm) (DMSO- $\left.d_{6}\right)$ : $\delta$ : benzene protons 7.94 (dd, $1.4 \mathrm{~Hz}, 8.4 \mathrm{~Hz}, 1 \mathrm{H}) ; 8.02$ (d, $4.5 \mathrm{~Hz}, 1 \mathrm{H}) ; 8.05$ (s, 1H); methyl 2.54 (s, 3H). ${ }^{13} \mathrm{C}$ NMR (ppm) (DMSO- $\left.d_{6}\right)$ : $\delta$ : benzene carbons 125.46, 128.94, 133.70, 134.36, 135.42, 152.32; methyl 19.95; COO 166.72.

4-Methyl-3-nitrobenzoic acid, 4- $\mathrm{CH}_{3}-3-\mathrm{NO}_{2}-\mathrm{C}_{6} \mathrm{H}_{3} \mathrm{COOH}$ : The parent acid, 4-methyl-3-nitrobenzoic acid, 4- $\mathrm{CH}_{3}-3-\mathrm{NO}_{2}-$ $\mathrm{C}_{6} \mathrm{H}_{3} \mathrm{COOH}$ was also purchased from Acros Organics and used without any further purification. FTIR as $\mathrm{KBr} \operatorname{disc}\left(\mathrm{cm}^{-1}\right)$ : selected data: $v(\mathrm{OH}) 2832-2546, v(\mathrm{COO})_{\text {as }} 1699, v(\mathrm{COO})_{\text {s }}$ 1319. ${ }^{1} \mathrm{H}$ NMR (ppm) (DMSO- $\left.d_{6}\right)$ : $\delta$ : benzene protons 7.58 (d, $7.8 \mathrm{~Hz}, 1 \mathrm{H}) ; 8.07$ (d, $7.9 \mathrm{~Hz}, 1 \mathrm{H}) ; 8.36$ (s, 1H); methyl $2.55(\mathrm{~s}, 3 \mathrm{H}) .{ }^{13} \mathrm{C}$ NMR $(\mathrm{ppm})\left(\mathrm{DMSO}-d_{6}\right)$ : $\delta$ : benzene carbons 125.79, 130.87, 134.18, 138.49, 149.57; methyl 20.54; COO 166.32 . 


\section{RESULTS AND DISCUSSION}

In this study, complexes 1-4 have been obtained in solid state. The micro-elemental analysis for C, H, N and Sn data obtained were in agreement with the predicted formula for complexes 1-4. Complexes 1-4 gave a sharp melting point indicated the isolation of fairly pure complexes. An outline of the proposed structure for complexes 1-4 are depicted in Fig. 1.

The $v(\mathrm{O}-\mathrm{H})$ bands for the acids were absent in the infrared spectra of salts and complexes 1-4 showed the deprotonation and coordination of the carboxylate anion. Complexes 1-4 revealed that the $\mathrm{v}(\mathrm{COO})_{\text {as }}$ was shifted to a lower wavelength number compared to the parent acids which signify that the coordination took place via the oxygen atoms of the carboxylate anion. Complexes 1-4 showed that the $v(\mathrm{COO})_{\text {as }}$ and $v(\mathrm{COO})_{\mathrm{s}}$ are in the range of 1641-1523 and 1407-1306 $\mathrm{cm}^{-1}$, respectively. Generally, the $\Delta v=\left[v(\mathrm{COO})_{\mathrm{as}}-\mathrm{v}(\mathrm{COO})_{\mathrm{s}}\right]$ value is used to determine the bonding properties of carboxylate anion to tin atom in organotin(IV) carboxylate complexes ${ }^{14}$. From the infrared spectra of complexes 1 and 3 , two $\Delta v$ values (329 and $183 \mathrm{~cm}^{-1}$ for complex 1 ; 179 and $123 \mathrm{~cm}^{-1}$ for complex 3) were observed. The $\Delta v$ values were either comparable or lower than the $\Delta v$ of the sodium salt of the respective acids, indicating that the carboxylate anions were bonded to the tin(IV) atom in a bidentate mode ${ }^{14}$. As a result, two tin(IV) atoms exhibited a distorted trigonal bipyramidal geometry and while another two tin(IV) atoms exhibited a distorted octahedral geometry in complexes $\mathbf{1}$ and $\mathbf{3}$.

For complexes derived from triphenyltin(IV) carboxylate, $\Delta v$ below $200 \mathrm{~cm}^{-1}$ would be expected for bridging or chelating carboxylates, but greater than $200 \mathrm{~cm}^{-1}$ for the monodentate bonding carboxylate anions ${ }^{15}$. Hence, the carboxylate anion in complexes $\mathbf{2}$ and $\mathbf{4}$ would be expected to bond to the tin(IV) atom in monodentate manner since the $\Delta v$ above $200 \mathrm{~cm}^{-1}$. Based on the elemental analysis, a methanol molecule was present in complexes $\mathbf{2}$ and 4 . It was believed that the methanol molecule have taken part in the coordination to the tin(IV) atom.
The absorption bands of the aliphatic and aromatic functional groups centered around $3000 \mathrm{~cm}^{-1}$ should be sharp, but they appear as small hump together with the $\mathrm{v}(\mathrm{OH})$ band observed in the region of $3641-3542 \mathrm{~cm}^{-1}$ in the spectra of complexes 2 and 4 which might be due to the effect of the methanol molecule. As a result, the tin(IV) atom of complexes $\mathbf{2}$ and $\mathbf{4}$ were five-coordinated and exhibited a trigonal bipyramidal geometry. For further information, similar case and structure has been reported by our research group ${ }^{16}$.

The ${ }^{1} \mathrm{H}$ NMR spectra of complexes 1-4 exhibited similarities to their parent acids. The ${ }^{1} \mathrm{H}$ NMR spectrum of each parent acid exhibited three sets of signals arising from the aromatic protons of the benzene ring. In the upfield regions of the ${ }^{1} \mathrm{H}$ NMR spectra of the complexes $\mathbf{1}$ and $\mathbf{3}$ showed the signal of the butyl protons in the range of 0.77-1.87 ppm, respectively. For complexes $\mathbf{2}$ and 4, the resonances appeared as two well separated sets of multiplets in the regions centering around $\delta \approx 7.51$ and $7.85 \mathrm{ppm}$ (downfield) with integration values of 9:6, respectively, ascribed to the aromatic protons of the phenyl group ${ }^{17}$.

Evidence of the formation of the complexes is displayed in the ${ }^{13} \mathrm{C}$ NMR spectra. The ${ }^{13} \mathrm{C}$ NMR spectra of complexes 1-4 showed the $\delta(\mathrm{COO})$ signal shifted to the downfield region which is lower compared to that of the parent acids indicating the carboxylate anion is bonded to tin(IV) atom. Complexes 1 and $\mathbf{3}$ were derivatives of organodistannoxane dimer types exhibited two sets of signals corresponding to the butyl groups in the ${ }^{13} \mathrm{C}$ NMR spectra. These two sets of signals were attributed to the butyl groups linked to the exo- and endo-cyclic tin(IV) atom, respectively ${ }^{18}$. Complexes $\mathbf{2}$ and $\mathbf{4}$ revealed the chemical shifts of the $\delta\left({ }^{13} \mathrm{C}\right)_{\text {ipso }}$ at 138.31 and $137.32 \mathrm{ppm}$, respectively indicative of a four-coordinated tin(IV) atom ${ }^{19-21}$. Generally, the ${ }^{1} \mathrm{H}$ and ${ }^{13} \mathrm{C}$ NMR spectra of the complexes obtain are found to exhibit no additional resonance and thus reflects the purity of the complexes. The ${ }^{1} \mathrm{H}-{ }^{13} \mathrm{C}$ HMQC NMR spectra of 4-methyl-3-nitrobenzoic acid and complex $\mathbf{1}$ are depicted in Figs. 2 and 3 as a representative.

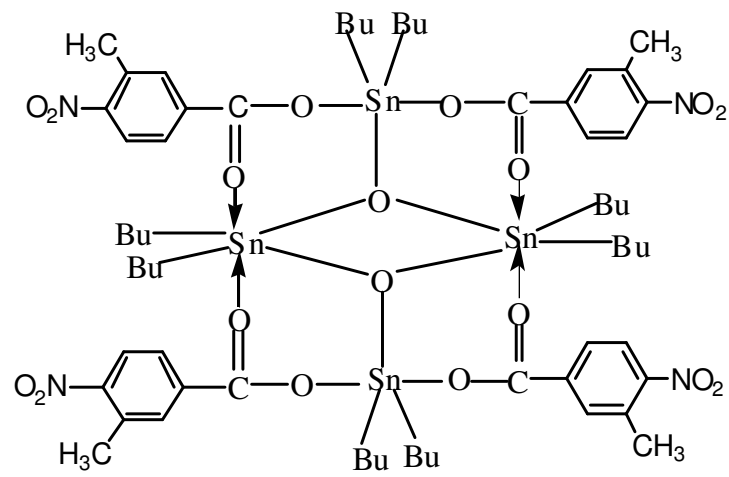

1<smiles>Cc1cc(C(=O)O[Sn](O)(c2ccccc2)c2ccccc2)ccc1[N+](=O)[O-]</smiles>

2

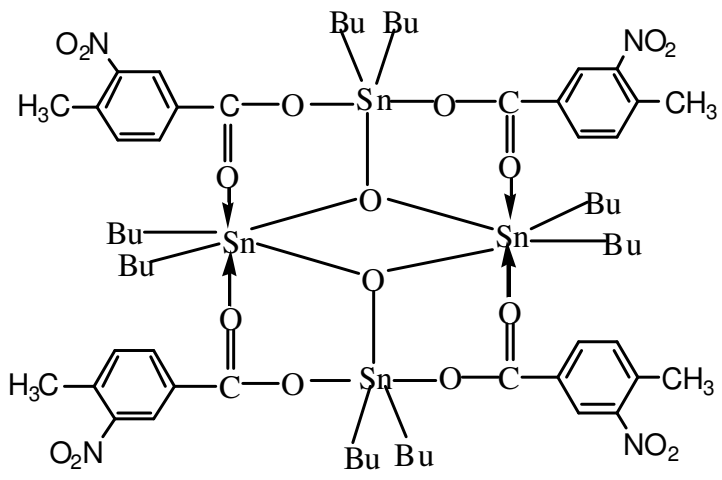

3<smiles>Cc1ccc(C(=O)O[Sn](c2ccccc2)(c2ccccc2)c2ccccc2)cc1[N+](=O)[O-]</smiles>

$\mathrm{Bu}=$ butyl \& $\mathrm{Ph}=$ phenyl

Fig. 1. Proposed structure for complexes 1-4 


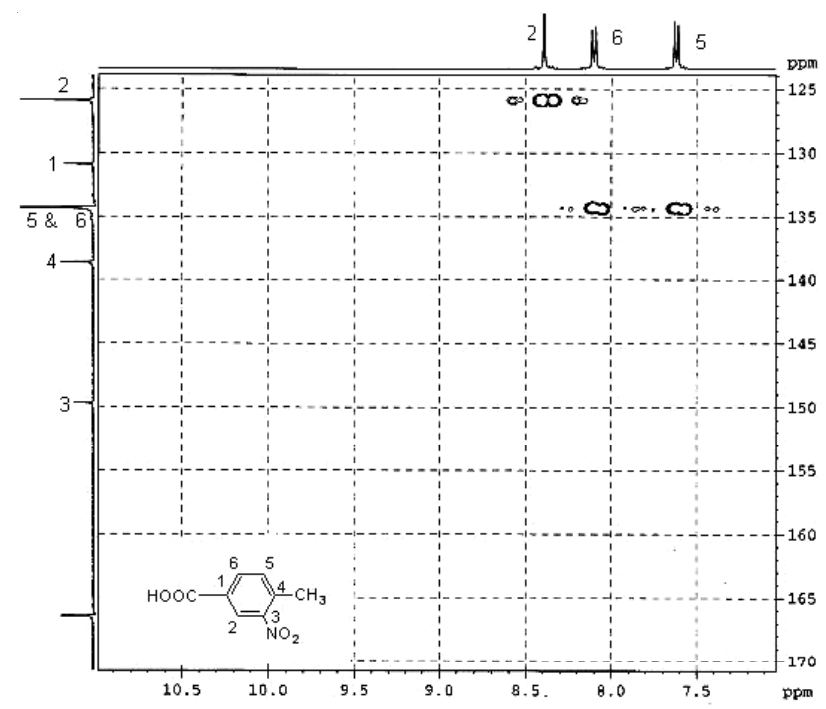

Fig. 2. ${ }^{1} \mathrm{H}-{ }^{13} \mathrm{C}$ HMQC NMR spectrum of 4-methyl-3-nitrobenzoic acid

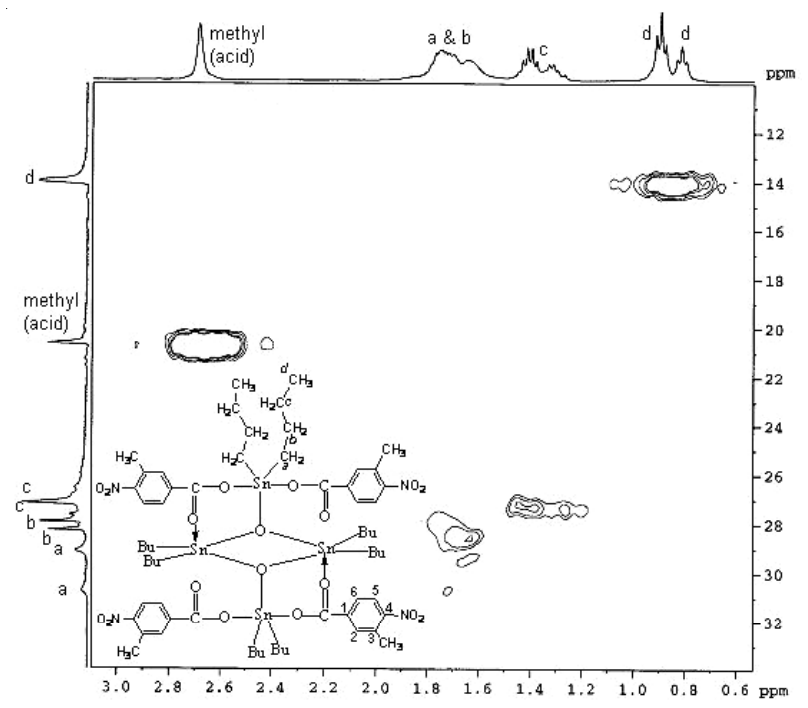

Fig. 3. ${ }^{1} \mathrm{H}-{ }^{13} \mathrm{C}$ HMQC NMR spectrum of complex $\mathbf{1}$

The $\delta\left({ }^{119} \mathrm{Sn}\right)$ value of the four-coordinated complexes fall in the range between +200 to $-60 \mathrm{ppm}$; the five-coordinated complexes between -90 to $-190 \mathrm{ppm}$ and the six-coordinated complexes between -210 to $-400 \mathrm{ppm}^{22}$. Complex derivatives of organodistannoxane dimer types usually exhibit two well resolved $\delta\left({ }^{119} \mathrm{Sn}\right.$ ) signals (complex $\mathbf{1}=-206.97,208.09 \mathrm{ppm}$; complex $\mathbf{3}=-207.39,-211.19 \mathrm{ppm}$ ). These two low- and highfield resonances were attributed to the exo- and endo-cyclic tin(IV) atoms ${ }^{8,18}$. Based on the ${ }^{119} \mathrm{Sn}$ NMR spectra, all the tin(IV) atoms in complexes $\mathbf{1}$ and $\mathbf{3}$ were five-coordinated and each exhibited a distorted trigonal bipyramidal geometry. Based on the infrared spectral studies, the carboxylate anions were bonded to the tin(IV) atoms of complexes $\mathbf{1}$ and $\mathbf{3}$ in a bidentate manner resulting in the tin(IV) atoms exhibiting either a five- or six-coordination geometry but based on the ${ }^{119} \mathrm{Sn}$ NMR spectral studies, all the tin(IV) atoms in complexes $\mathbf{1}$ and $\mathbf{3}$ were five-coordinated. This maybe due to the disassociation of the bidentate bonds upon dilution during the preparation of the NMR sample in solution form. Complexes $\mathbf{2}$ and 4 showed that the $\delta\left({ }^{119} \mathrm{Sn}\right)$ values at -103.30 and $-100.11 \mathrm{ppm}$ which lie in the range of -40 to -120 ppm [for triphenyltin(IV) complexes], hence, indicating that the tin(IV) atoms in complexes $\mathbf{2}$ and $\mathbf{4}$ are four-coordinated with a distorted tetrahedral geometry ${ }^{19,20}$. From the ${ }^{119} \mathrm{Sn}$ NMR spectral studies, it is believed that methanol molecule was disassociated upon dilution during the NMR solution preparation resultant tin(IV) atom in complexes $\mathbf{2}$ and $\mathbf{4}$ remained four-coordinated. In another words, this phenomenon may due to the coordinating bond of the methanol is not strong compared to that of the carboxylate anions.

Preliminary in vitro antibacterial screening activity: The preliminary in vitro antibacterial screening activity of parent acids and complexes 1-4 are given in Table-1. Inhibition zones with a diameter less than $10 \mathrm{~mm}$ are considered as weak; larger than $10 \mathrm{~mm}$ but less than $16 \mathrm{~mm}$ are considered as moderate and finally larger than $16 \mathrm{~mm}$ and above are active $^{7,23}$. Based on this study, complexes $\mathbf{2}$ and $\mathbf{4}$ which were derivatives of triphenyltin(IV) were found to be more active compared to the diorganotin(IV) complexes (1 and $\mathbf{3}$ ) and parent acids against Bacillus subtilis, Pseudomonas aeruginosa and Staphylococcus aureus but lower compared to the reference drugs. Based on the structural-activity study, complexes $\mathbf{2}$ and $\mathbf{4}$ were found to be more active due to both complexes were obtained as simple a monomer, four-coordinated and exhibited tetrahedral $\left(s p^{3}\right)$ in solution form whereas complexes $\mathbf{1}$ and $\mathbf{3}$ obtained as a bulky molecule with a complicated structure which in turn restrict their mobility to the target cell or active site. Moreover, based on the data in Table- 1 showed that complexes $\mathbf{2}$ and $\mathbf{4}$ were completely inactive against Klebsiella pneumoniae bacterial strains in this study.

\begin{tabular}{|c|c|c|c|c|c|}
\hline \multicolumn{6}{|c|}{$\begin{array}{c}\text { TABLE-1 } \\
\text { PRELIMINARY IN VITRO ANTIBACTERIAL SCREENING ACTIVITY OF PARENT ACID AND COMPLEXES 1-4 }\end{array}$} \\
\hline \multirow[b]{2}{*}{ Complexes } & \multicolumn{5}{|c|}{ Inhibition zone $(\mathrm{mm})$} \\
\hline & $\begin{array}{l}\text { Bacillus } \\
\text { subtilis }\end{array}$ & $\begin{array}{l}\text { Escherichia } \\
\text { coli }\end{array}$ & $\begin{array}{c}\text { Klebsiella } \\
\text { pneumoniae }\end{array}$ & $\begin{array}{l}\text { Pseudomonas } \\
\text { aeruginosa }\end{array}$ & $\begin{array}{l}\text { Staphylococcus } \\
\text { aureus }\end{array}$ \\
\hline $3-\mathrm{CH}_{3}-4-\mathrm{NO}_{2}-\mathrm{C}_{6} \mathrm{H}_{3} \mathrm{COOH}$ & 8 & 8 & 9 & 11 & 12 \\
\hline 1 & 9 & 7 & 10 & 7 & 11 \\
\hline 2 & 18 & - & - & 22 & 17 \\
\hline $4-\mathrm{CH}_{3}-3-\mathrm{NO}_{2}-\mathrm{C}_{6} \mathrm{H}_{3} \mathrm{COOH}$ & 11 & 9 & 10 & 12 & 11 \\
\hline 3 & 12 & 7 & 9 & 20 & 13 \\
\hline 4 & 20 & 8 & - & 22 & 17 \\
\hline Chloramphenicol & 29 & - & 23 & 34 & 30 \\
\hline Doxycycline & 34 & 24 & 21 & 40 & 28 \\
\hline Rifampicin & 25 & 24 & 23 & 29 & 37 \\
\hline
\end{tabular}




\section{Conclusion}

Complexes 1-4 have been successfully synthesized. The structural as well as the coordination number of tin(IV) moieties of complexes 1-4 have been successfully characterized quantitatively and qualitatively. Based on the preliminary in vitro antibacterial screening activity, complexes $\mathbf{2}$ and $\mathbf{4}$ [triphenyltin(IV)] showed better activity compared to complexes $\mathbf{1}$ and $\mathbf{3}$ [diorganotin(IV)] but lower activity compared to the reference drugs.

\section{ACKNOWLEDGEMENTS}

The authors thank Universiti Tunku Abdul Rahman (UTAR) for the UTAR Research Fund (Project No. IPSR/RMC /UTARRF/C1-11/C07) and Universiti Sains Malaysia (USM) for financial support as well as technical assistance and facilities.

\section{REFERENCES}

1. K.C. Molloy, T.G. Purcell, K. Quill and I.W. Nowell, J. Organomet. Chem., 267, 237 (1984).

2. R. Willem, A. Bouhdid, B. Mahieu, L. Ghys, M. Biesmans, E.R.T. Tiekink, D.D. Vos and M. Gielen, J. Organomet. Chem., 531, 151 (1997).

3. S.G. Teoh, S.H. Ang, S.B. Teo, H.K. Fun, K.L. Khew and C.W. Ong, J. Chem. Soc. Dalton Trans., 465 (1997).

4. F. Novelli, M. Recine, F. Sparatore and C. Juliano, IL Farmaco, 54, 237 (1999).

5. M. Gielen, M. Biesemans, D.D. Vos and R. Willem, J. Inorg. Biochem., 79, 139 (2000).
6. K.A. Crouse, K.-B. Chew, M.T.H. Tarafder, A. Kasbollah, A.M. Ali, B.M. Yamin and H.K. Fun, Polyhedron, 23, 161 (2004).

7. Y.-F. Win, S.-G. Teoh, M.R. Vikneswaran, S.-T. Ha and I. Pazilah, Int. J. Phys. Sci., 5, 1263 (2010).

8. Y.-F. Win, S.-G. Teoh, S.-T. Ha, L.G.-A. Ong and T.-S. TengkuMuhammad, Int. J. Phys. Sci., 6, 1463 (2011).

9. R. Zhang, J. Sun and C. Ma, J. Organomet. Chem., 690, 4366 (2005).

10. Y.F. Win, S.G. Teoh, J.B.-J. Teh, H.K. Fun and L. Zakaria, Acta Cryst., E63, m323 (2007).

11. Y.F. Win, S.G. Teoh, M.R. Vikneswaran, J.H. Goh and H.K. Fun, Acta Cryst., E66, m695 (2010)

12. Y.-F. Win, C.-S. Choong, S.-T. Ha, C.K. Quah and H.K. Fun, Acta Cryst., E67, m535 (2011).

13. M.M. Amini, A. Azadmeher, V. Alijani, H.R. Khavazi, T. Hajiashrafi and A.N. Kharat, Inorg. Chim. Acta, 362, 355 (2009).

14. G.K. Sandhu and S.P. Verma, Polyhedron, 6, 587 (1987).

15. L.L. Yeap and S.G. Teoh, J. Coord. Chem., 56, 701 (2003).

16. F.W.Yip, S.G. Teoh, B.M. Yamin and S.W. Ng, Acta Cryst., E66, m1164 (2010).

17. A. Sau and R.R. Holmes, J. Organomet. Chem., 217, 157 (1981).

18. M. Danish, H.G. Alt, A. Badshah, S. Ali, M. Mazhar and N. Islam, J. Organomet. Chem., 486, 51 (1995).

19. J. Holecek, K. Handlír, M. Nádvornik and A. Lycka, J. Organomet. Chem., 258, 147 (1983).

20. J. Holecek, M. Nadvorník, K. Handlír and A. Lycka, J. Organomet. Chem., 241, 177 (1983).

21. T.S.B. Baul, S. Dhar, S.M. Pyke, E.R.T. Tiekink, E. Rivarola, R. Butcher and F.E. Smith, J. Organomet. Chem., 633, 7 (2001).

22. J. Holecek, M. Nádvornik, K. Handlír and A. Lycka, J. Organomet. Chem., 315, 299 (1986).

23. Z.H. Chohan, M. Arif, M.M. Akhtar and C.T. Supuran, Bioinorganic Chemistry and Application, 1 (2006). 